\title{
The THEOlOGiCAL RESPONSES TO THE SOCIO-ECONOMIC ACTIVITIES THAT UNDERMINE WATER AS A RESOURCE
}

Author:

Thomas Resane ${ }^{1,2}$

\section{Affiliations:}

${ }^{1}$ Assemblies of God,

Kempton Park,

South Africa

${ }^{2}$ Department of Systematic

Theology and Christian

Ethics, Faculty of

Theology, University of

Pretoria, South Africa

\section{Correspondence to:}

Thomas Resane

email:

thomas@yfcsr.co.za

Postal address:

PO Box 9463, Edenglen

1613, Johannesburg,

South Africa

\section{Keywords:}

creation; earth; economic activities; humans; nature; resources; theology; water

\section{Dates:}

Received: 04 Aug. 2009

Accepted: 22 Dec. 2009

Published: 02 June 2010

How to cite this article:

Resane, T., 2010, 'The

theological responses

to the socio-economic

activities that undermine

water as a resource',

HTS Teologiese Studies/

Theological Studies 66(1),

Art. \#328, 7 pages. DOI:

10.4102/hts.v66i1.328

This article is available

at:

http: / / www.hts.org.za

\section{Note:}

Dr Thomas Resane is a research associate of Prof.

Dr Johan Buitendag, Dean of the Faculty of Theology, Department of Systematic Theology and Christian Ethics, University of Pretoria.

(C) 2010. The Authors. Licensee: OpenJournals Publishing. This work is licensed under the Creative Commons Attribution License.

\section{ABSTRACT}

This article focuses, from a theological perspective, on both the ecological crisis and the politico-economic dealings in relation to water - especially with regard to the unsound ways in which governments deal with this resource. Texts are read from an anthropogenic perspective, as opposed to an anthropocentric one. Such a reading scenario calls for responses from theology with regard to the human position in creation. Humans are not a grand master plan of creation, but the completion and fulfilment of it, given an enormous sense of responsibility for the earth.The article argues that the human-earth relation should be understood from the point of responsibility based on solidarity, interdependency and stewardship. Theologians are challenged to embrace eco-ethics.

\section{INTRODUCTION}

\section{South African political view of water and its management}

In 1994, the African National Congress and its Alliance partners came up with a policy framework known as The Reconstruction and Development Programme (RDP). Chapter 2 of the document addresses the importance of meeting the basic needs. It claims that water, as 'a natural resource should be made available in a sustainable manner to all South Africans' (1994:28). The document continues to emphasize the fact that

the fundamental principle of our water resources policy is the right to access clean water - 'water security for all'. The RDP recognizes the economic value of water and the environment, and advocates an economically, environmentally and politically sustainable approach to the management of our water resources and the collection, treatment and disposal of water.

(1994:28-29)

\section{The National Water Act, 1998}

The National Water Act controls pollution of water sources, regulates water use, water-use charges, the protection of water resources and the granting of licenses to use water. The Act is important, as water is a limited resource in South Africa. This Act creates a hierarchy of water requirements, the first being the maintenance of a reserve needed to maintain the natural environment. Water users are invited to apply for licenses in respect of a particular water use and the procedures for this application are set out in the National Water Act. The license then may, or may not, be issued, or may be issued subject to conditions, including conditions governing permissible levels of chemicals in discharged wastewater.

According to the rights enshrined in South Africa's Constitution, Chapter 2, everyone has the right to an environment that is not harmful to their health or well-being, as well as the right to have the environment protected, for the benefit of present and future generations, through reasonable legislative and other measures, which:

- prevent pollution and ecological degradation

- promote conservation

- secure ecologically sustainable development and use of natural resources, while promoting justifiable economic and social development (RDP 1994:20-28).

\section{The South African Environment Policy}

The South African Environment Policy continues to emphasise that the following should be given priority regarding water management:

- the identification of liabilities in terms of environmental legislation applicable to those activities causing pollution of water resources

- water licensing applications

- the review of policies and strategies pertaining to water management and applying these to specific operations

- the promotion of water conservation practices.

\section{FACTS ABOUT THE WATER SITUATION}

\section{The Christian view}

Until recently, the majority of Christian theologians ignored the plethora of planet-wide issues documented in diverse and dispersed environmental science and policy literature. All the fields of theological disciplines acknowledge that the problem of natural resources management, such as water, is an inevitable topic to be addressed from the theological point of view. Susan Power Bratton calls to the attention that 'environmental activism was, after all, fostered by social malcontents and political radicals' (Stackhouse et al. 2000:113). Theologians who believe in the Christian responsibilities to the 
hungry and thirsty - the poor and marginalised - can hardly turn their faces away from changes in the earth's habitats that cause food and water shortages. This is the task of a theology of nature: to use 'the contemporary picture of reality from the sciences of its day as a resource to reconstruct and express the faith' (McFague 1993:66).

\section{The realistic scenario}

Water is life. These words convey the importance of water on Earth. Earth is the only planet in our solar system on which water occurs in liquid form on land and, therefore, probably the only planet where life can develop and flourish. The hydrological cycle of water (continuous circulation of water from the sea to the atmosphere, to the land and back to the sea) necessitates precipitation in the form of rain to refresh and replenish the earth making it productive and balancing the ecosystem. This makes water a renewable, but simultaneously irreplaceable, resource. Human-environment interactions result in significant changes in the natural water balance. Water has always been a centripetal force impacting the lifestyle of communities. It is significant in religious rituals, domestic courtesy and economic activities.

Water is our most abundant resource on a global scale, yet there are areas with deficiencies and surpluses. Only a tiny fraction of it is available to the ecosystem as fresh water; moreover, this fraction is distributed very unevenly around the world. Miller enlightens us to the fact that

about $97 \%$ of Earth's volume of water is found in the oceans and is too salty for drinking, growing crops, and most industrial uses except cooling. The remaining 3\% is fresh water. About $2.99 \%$ of this is locked up as ice at the poles and in glaciers or is groundwater that is too deep and too expensive for us to extract. This means that only about $0.003 \%$ of Earth's total volume of water is easily available to us in lakes, soil moisture, exploitable groundwater, atmospheric water vapor, and streams.

(Miller 1992:334)

The usage of water can be classified in terms of withdrawal and non-withdrawal. Withdrawal usage is when the water is diverted from its source, such as from a spring, a well, or a stream. At its source for activities such as navigation or recreation, it is defined as non-withdrawal usage. The demand for the withdrawal of water for the purpose of generating power is high, compared to other demands on withdrawal use. The fact is that, over five decades ago, it was discovered that 'more than six times as much water is used for water power than for all other withdrawal uses combined' (Finch 1957:394). There has not been much change since. This is unfortunate because political treatises and accords are involved, especially if the water is to be diverted to another territory or country. South Africa gets the bulk of its hydroelectricity from Cahorra Bassa in Mozambique and ironically sells the same electricity back to Mozambique, with a substantial profit. Cahorra Bassa is one of Africa's larger fresh water catchments, with its main tributary being the mighty Zambezi River. The dam lies in western central Mozambique, forming a 'corner' where it meets with Zambia and Zimbabwe. The lake is more than $280 \mathrm{~km}$ long and is surrounded by millions of hectares of unutilised and spectacular mountainous countryside that surrounds its varying shoreline.

The same can be said about the Lesotho Highlands Water Project, which supplies South Africa with water at the expense of Lesotho's natural vegetation. The Lesotho Highlands Water Project is an ongoing water supply project, with a hydropower component, developed in partnership between the governments of Lesotho and South Africa. It comprises a system of several large dams and tunnels throughout Lesotho and South Africa. In Lesotho, it involves the rivers Malibamatso, Matsoku, Senqunyane and Senqu. In South Africa, it incorporates the Vaal River. It is Africa's largest water transfer scheme. The purpose of the project is to provide Lesotho with a source of income, in exchange for the provision of water to the central Gauteng province where the majority of industrial and mining activity occurs in South Africa, as well as to generate hydroelectric power for Lesotho (currently almost 100 per cent of Lesotho's requirements).

\section{THE HUMAN IMPACT ON WATER}

The human impact on the hydrosphere, as highlighted by Lvovitch and Solokov (1976), has recently taken the following forms (with my personal commentaries):

\section{Agricultural practices}

Agricultural practices, aimed at increased food production, have had an effect on the regulation of the water balance in the soil. Unpredictable changes in rainfall patterns, brought about by a possible enhanced greenhouse effect, are likely to cause great disruptions in agricultural areas. Today, agriculture accounts for 70 per cent of all water use globally, up to 95 per cent in several developing countries. To keep pace with the growing demand for food, it is estimated that 14 per cent more freshwater will need to be withdrawn for agricultural purposes in the next 30 years. Added to the pressures of agricultural use, is the increased awareness of the instrumental value of water in maintaining environmental services and ecosystem resilience. Increasing the efficiency of water use and enhancing agricultural water productivity at all levels in the production chains, is becoming a priority in a rapidly growing number of countries. A systematic approach to agricultural water productivity requires actions at all levels: from crops to irrigation schemes, to national and international economic systems, including the trade in agricultural products. This calls for an informed discussion about the possibilities of optimising water usage, as well as ameliorating intersectoral competition for water resources and improving socio-economic outcomes.

\section{Increasing water consumption}

Increasing water consumption in dry regions results in the exhaustion of freshwater supplies. Incidences of catastrophic events, such as droughts, interrupt educational attainment, drought preparedness programmes and developmental goals.

\section{Stream flow regulation and the building of large dams}

Stream flow regulation and the building of large dams have an effect on the temporal and spatial distribution of water. For example, the Lesotho Highland Water Project's impact on the people and agricultural output needs to be reconsidered, in spite of the monetary income generated by the project.

\section{Urbanisation}

Urbanisation, and mining in particular, involves the excavation and removal of large masses of water; actions which disturb the balance between surface and ground water. As the population increases, so too does industrialisation, which will lead to an intensification of water supply crises in regions that are already experiencing water shortages. Urbanisation also increases flooding, even where there is a moderate rainfall. It replaces vegetation and soil with highways, parking lots, shopping complexes and other gigantic building structures that lead to the rapid runoff of rainwater. A common feature of water management in South Africa is that large quantities of water required for withdrawal use by modern urban and industrial centres are obtained from wells, springs, dams and large rivers and, even more frequently, from small streams, the drainage of which is being stored in municipal reservoirs.

\section{Pollution of rivers, lakes, dams and ground water}

The pollution of rivers, lakes, dams and ground water by industrial, agricultural and household effluents, could lead to the qualitative exhaustion of the water resources. An example of 
this can be found in the effect of the Jukskei River that originates in Bruma, east of Johannesburg, and runs through the Alexandra township and some farming patches of land north of the city, before pouring its contaminated water into the Hartebeespoort Dam, where eutrophication is a challenge for both the Department of Water Affairs and Environmental Affairs. Early in 2009, The Citizen newspaper published a warning that '[r] esidents living on the banks of the Jukskei River have been warned not to use the water for washing or drinking' (The Citizen 23 March 2009:5). The newspaper article continued to inform the residents that ' $[\mathrm{c}]$ holera and other bacteria have been found contaminating the river which runs from Johannesburg to Hartebeespoort Dam.' The Jukskei River collects phosphates and nitrates from the drainage systems, the combination of which forms a fertilizing agent that enhances and expedites the growth of algae, which now covers the surface of the catchment of the Hartebeespoort Dam. Generally speaking, the Jukskei River goes through a process that

in its passage through hydrologic cycle, water is polluted primarily by three kinds of waste. One is the sediment washed from the land into surface waters by natural erosion and by greatly accelerated erosion of soil from agriculture, forestry, mining, construction, and other land-clearing and disturbing activities.

(Miller 1992:341)

\section{POLITICISATION OF WATER}

\section{The political impact on freshwater}

In March 2006, the 2nd UN World Water Development Report was launched in Mexico, on Water Day. The theme was 'Water: A crisis of governance', wherein it was resolved that the fundamental fact that needed to be understood by the world was the following:

water is essential for all socio-economic development and for maintaining healthy ecosystems. As population increases and development calls for increased allocations of groundwater and surface water for the domestic, agriculture and industrial sectors, the pressure on water resources intensifies, leading to tensions, conflicts among users, and excessive pressure on the environment. The increasing stress on freshwater resources brought about by ever rising demand and profligate use, as well as by growing pollution worldwide, is of serious concern.

(United Nations 2006)

The Lesotho Highlands Water Project is cited as a relevant example. The project has been alleged to have had negative social and environmental effects. While compensation was provided in kind and paid to the few hundred households affected by the dams, there is criticism that it has been insufficient. It was not utilised to address the water supply problems in Lesotho, but to pay royalties to the Lesotho Government for development purposes, whereby very few benefits have reached the affected population. In recent years, water from the scheme has been discharged into the Mohokare (Caledon) River to provide water to Maseru in times of critical shortages. The new dams have filled, as anticipated, and discharge of water from the dams into the downstream rivers continues in a scheme devised to preserve ecological balance. This discharged water flows to the Senqu (Orange) River, preserving the ecological status quo, but benefiting only those communities who live along the rivers.

\section{The scarcity of water}

The United Nations Water Scarcity Thematic Initiatives of 2006 alert us to the fact that water use has been growing at more than twice the rate of population increase in the last century and, although there is no global water scarcity as such, an increasing number of regions are chronically short of water. By 2025, 1800 million people will be living in countries or regions with absolute water scarcity and two-thirds of the world's population could be under stress conditions. The situation will be exacerbated, as rapidly growing urban areas place heavy pressure on neighbouring water resources. The good news is that this supply of fresh water is continually collected, purified, and distributed in the hydrologic cycle. The global average for replacement of water in streams is about two decades, while water in the atmosphere can be replaced every 10 to 12 days. However, the deep groundwater requires several hundred years for renewal, except for deep fossil aquifers, which are nonrenewable on a human time scale.

According to a 2007 World Health Organization (WHO) report, 1.1 billion people lack access to an improved drinking water supply, 88 per cent of the 4 billion annual cases of diarrheal disease are attributed to unsafe water and inadequate sanitation and hygiene and 1.8 million people die from diarrheal diseases each year. The WHO estimates that 94 per cent of these diarrheal cases are preventable through modifications to the environment, including access to safe water. Simple techniques for treating water at home, such as chlorination, filters, solar disinfection and storing it in safe containers, could save a huge number of lives each year.

\section{WATER AND THE BIBLE}

\section{Water and life}

Water symbolises life in the Bible, serving various purposes therein. Old Testament laws required water be used for spiritual cleansing, for example in ritual bathing, which signifies spiritual purification. God showed a special love for his people by miraculously providing water in times of drought; in this way he foreshadows the New Testament revelation that Christ is the source of living water. God had power over the water of the Red Sea and thus could save his people and destroy his enemies at the same time. The water of the restless sea is used as a symbol of evil and judgement, for which reason heaven is described as having no 'sea' (Rv 21:1). The final resting place for God's people has peaceful 'waters' ( $R v$ 22:1-2).

\section{Domestic courtesy}

There is an abundance of texts that demonstrate the use of water for courtesy in the homestead. (Gn 18:4, 19:2, 43:24, 24:32; $1 \mathrm{Sm}$ 25:4; Jn 13:5). The New Testament feet washing ceremony was taken over from the Old Testament as a ritual for welcoming guests into the house (Lk 7:44; Jn 13:5).

\section{Purification rites}

Ceremonial cleansing was common in both the Old Testament and the New Testament: one can think of Pharaoh's daughter going to the River Nile to bathe, or the refusal of Naaman to dip himself in the River Jordan seven times.

\section{Temple rites}

Water played a significant role in the sacrificial offerings and the consecration of the priests. For instance, there was a laver (basin) placed directly in front of the altar of burnt offering. Its function was to 'contain the waters of purification with which the priests must wash their hands and feet before they could officiate at any of the tabernacle services' (Merrill 1994:143). Therefore, it was an important element of the service at, and around, the tabernacle (Nm 5:17, Ex 29:4, 30:18).

\section{Agricultural activities}

As in many economic activities, agricultural prosperity was dependent on the abundance of water. The absence of rain consequently led to famine. Drought also influenced population or community migration. This is demonstrated by the story of Elimelech and Naomi in the book of Ruth. It was also due to famine that Isaac had to move to Gerar, where he deceived the king about his wife, as his father Abraham had done (Gn 26). During the ministry of Elijah the prophet, it was abundantly 
clear that agricultural prosperity was dependent on the abundance of rain. The availability of water ensured abundance and prosperity.

\section{Population settlement}

From the patriarchal era, the water source was a determining factor that effected the population settlement. It was the social place for people to meet. The importance of water held by the pastoralists of the Old Testament is found in Genesis 30, here several groups of herders gathered around a well near Haran. No one dared water his sheep until all of the herders had assembled. 'An accusation that one was getting more than his fair share might have led to armed conflict' (Matthews 1990:17). It was also by the well in Paddan Aram that Jacob met Rachel. It looks like the water was place for normal body cleansing as we see with Pharaoh:

Then the LORD said to Moses, 'Rise up early in the morning and present yourself to Pharaoh, as he goes out to the water, and say to him, "Thus says the LORD, Let my people go, that they may serve me"'.

It was by the River Nile where Pharaoh's daughter discovered the baby Moses. It was by the well where Moses met Jethro's daughters in Midian. These encounters by a water source demonstrate that human populations used nearby water sources for socio-political interactions.

The presence of water directed the movements of pastoral peoples, in this case, Abraham and Lot, whose herders experienced conflict over the use of the wells. They settled where it was possible to dig wells, an activity which took precedence over everything else, including the erection of altars. The number of sustainable wells had a direct influence on the prosperity of the partriarchs: negotiations for their use were taken to the highest level, for example in Genesis 20 and 26 where they had to bargain with Abimelech (king of Gerar) for access to his wells. Genesis 26 illustrates the importance of water by the digging of the wells and how this brought prosperity to the patriarchs. Genesis 20 and 26 shows how the patriarchs had to negotiate with Abimelech, the king of Gerar, for usage of wells in his region. They obtained permission to access water as a result of the wife-sister deception - embarrassment that caused eventual friction between the herders and the people of Gera, who also needed water for their own livestock and fields. Gradually, as the men of Gerar confiscated his wells, Isaac and his shepherds were driven further south towards Beersheba. This gave them some freedom and independence to dig wells that would legitimately belong to them.

These two chapters (Gn 20 \& 26) tell us that there were specific zones designated for use by the urban-based communities, within which the outsiders were grudgingly given water rights and grazing resources. When the leaders of a community felt that the pastoral nomads were threatening the welfare of their economy, they would certainly force them to leave.

For the shepherds to survive, access to water was essential. The livestock could not go for more than three days without water. The knowledge of wells and springs was the most valuable and guarded pieces of information in a communal settlement. Victor H. Matthews (1990:17) points out that 'this knowledge and the right to use water resources is only shared with close kin and allied groups.' During the wilderness wanderings the Israelites always settled around springs. 'Then they came to Elim, where there were twelve springs of water and seventy palm trees, and they encamped there by the water' (Ex 15:27). At Marah, the water was too bitter to drink, hence the name 'marah', which means 'bitter'. The water became palatable after Moses cast a certain medicinal plant into it. From Marah, they journeyed to Elim (palms). 'And they set out from Marah and came to Elim; at Elim there were twelve springs of water and seventy palm trees, and they camped there' (Num 33:9). From there they journeyed to Rephidim, where Moses struck a rock to secure water.

\section{Sustenance of city life}

Life in the city was also sustained and developed in terms of the nature and the source of the available water. The city of Jerusalem had a brook that provided it with water. Merrill (1994:204) informs us that there was an adequate water supply because of a tunnel leading from the city cistern to an underground spring in the Kidron Valley.' The Kidron Brook was utilised in the cleansing of idolatry in Judah, as is demonstrated by the three Davidic kings burning idols in its vicinity: Asa (1 Ki 15:13; 2 Chr 15:16); Josiah (2 Ki 23:4-12); and Hezekiah (2 Chr 29:16, 30:14). Dirt associated with idolatry was washed out of the city through the brook. The kings constructed water canals to ensure water provision for the city dwellers. During wars, the supply could be sabotaged, placing the city under siege and forcing its inhabitants to surrender. This strategy was used by King Hezekiah in order to deprive the attacking Assyrians of water (2 Chr 32:4)

\section{The Lord Jesus Christ and the future role of water}

Our Lord Jesus Christ crossed Kidron Brook on his way out of the city after the Last Supper, on his way to the Garden of Gethsemane on the slopes of Mount of Olives (Jn 18:1). He also crossed it on his triumphal entry into Jerusalem.

The eschatological vision of the future City of God (Jerusalem) has always been one which included rivers flowing through and around it. For instance, Jeremiah mentions it in his prophecy regarding the rebuilding of Jerusalem (Jr 31:38-40).

\section{Water, baptism and Spirit}

Water is used as a symbol in baptism - combining the symbolism of spiritual cleansing, God's saving love, through the blood of Christ, that washes away sin and God's judgement on sin. It is for this reason that water and Spirit are associated in both biblical and theological references. Ray (2006) elaborates the relationship between earth, air, water and fire. In reference to water and Spirit, she unashamedly notes:

As the 'living water' the Spirit quickens and refreshes all who drink from its eternal springs (John 3:1-15; 4:14; 7:37-38). As physical and spiritual sustenance, the Spirit is the liquid God who imbues all life-sustaining bodily fluids - blood, mucus, milk, sweat, urine - with flowing divine presence and power. Moreover, the Water God flows and circulates within the soaking rains, dewy mists, thermal springs, seeping mudholes, ancient headwaters, swampy wetlands, and teeming oceans that constitute the hydrospheric earth we all inhabit. The Spirit as water makes possible the wonderful juiciness and succulence of life as we experience it on a liquid planet sustained by nurturing flow patterns.

(Ray 2006:124-125)

\section{THE THEOLOGICAL ALTERNATIVES}

\section{The problem of a hermeneutical approach}

The theological research problem of this paper is that socioeconomic activities compromise the quality of water as a resource for the sustenance of life and without water, there is no life - 'Water is life'. However, water can also bring on disasters: it carries bacteria responsible for diseases such as cholera and dysentery, it can come in the form of floods, causing loss of property and general destruction of the infrastructure, leaving populations destitute and unprotected. In light of this, there must be some theological response to the volatile water situation. This is viewed from the vantage of human-earth relationship.

\section{Anthropocentric approach}

The reason for theological shortcomings in preserving natural resources, such as water, is anthropocentric hermeneutics, which must be replaced with eco-hermeneutical anthropogenesis. The traditional approach to reading a text is anthropocentric, whereby humans are considered elevated and in charge, regarding the 
cosmological interpretation of texts. The fundamental conclusion in modern cosmology,

is the realization that cosmos is cosmogenesis and that anthropology is anthropogenesis. Everything is in a process of genesis and gestation; nothing is utterly finished, and anything is open to further acquisitions. The given is never given but appears as made out of the potentialities in reality, which are not exhausted in a particular given but are ever active-fashioning, refashioning, and completing each given.

(Boff 1997:176)

This anthropocentric approach elevates humans as readers, with the assumption that 'we are beings of a totally different order than all other creatures in nature ... the hierarchy of things is God, human beings, and the rest' (Habel 2008:4). Humans tend to forget that they are the 'laat lammetjies' (late-comers) of the creation. This anthropocentric bias inevitably relates to nature as object. Humans have, for time immemorial, subjected earth to human scientific analysis - the process that has elevated humans above nature, while simultaneously exacerbating a sense of distance, separation and otherness. Nature has become a force to be harnessed, to be exploited for the benefit of the human survival. It must be considered that, as part of creation, the Creator God is eschatologically involved in reshaping and reforming humanity into his likeness and character.

\section{Anthropogenic approach}

On the other hand, an anthropogenic approach consider humans to be both central and interdependent in relation to nature, whereby both grow together, while serving each other in some responsible manner. McFague (2008:90) refers to this as 'synergism of planetary operation', whereby the various parts of the planet work together to create something either better or worse than the individual parts. This is what Moltmann (1985:212-213) calls 'the open system', where the creative activity of God in history is in the process towards conclusion and completion of the open and the opened systems. The whole creation was given the stamp of approval so that at the end of each creative act, God could say: 'It is good'. The use of the term 'good' is impressive in the creation story. It is one of the several key words used in the creation story in multiples of seven - a mark of conscious artistry in the writing of the Genesis account. It views humans and the earth as a whole, existing in cosmological harmony. The word 'good' was also the final word of God the Creator at the end of the sixth day, after both man and woman were created (Gn 1:31)

Humanity and the earth are interrelated, interconnected and interdependent, hence the Lord could intimate to Adam: 'By the sweat of your brow you will eat your food until you return to the ground, since from it you were taken; for dust you are and to dust you will return' (Gn 3:19). There is a virtual identity of the human with the earth. Humans are totally dependent upon the soil. Peters (2000) summarises it as follows:

Not only do vegetables and fruits come directly from seeds sown in the ground, but even such products as milk and hamburger begin as grass that is transmuted by bovine digestive processes. We come from the soil, and when we die we are buried, we return to it. We come from dust and shall return to dust. We are soil.

(Peters 2000:148)

Humans were made from the dust and will return to the dust the very name 'Adam' means 'dust.' Habel (2000) points out that

God has consecrated creation by calling it forth (And God said, 'Let there be...'), by speaking to creation (e.g. Gen 1.29-31), and by pronouncing it very good (Gen 1.31). In these actions, God has sanctified everything God has created.

(Habel 2000:212)

Anthropogenesis proposes a picture of continuum, which embraces interrelationship and interdependence, whereby humans and all of the earth are an integrated, healthy whole.
This, if well balanced, will eliminate the consumer culture which views humanity as the chef d'oeuvre of creation, a masterpiece of its own making. Humans are expected to embrace creation á bras ouverts and á deux mains - with open arms and with both hands.

\section{Alternative approach}

Solidarity: Solidarity of humans with the earth can help us to address the problem of water wastage and mismanagement. There must be the common understanding of what the earth and all its resources mean within a broader ecological maxim. The present water scenario calls for camaraderie and team spirit, here humanity and the earth intertwine to bring sense to human responsibility in the cosmos. The earth-human relationship must be based on kinship, whereby the network of relationships is woven by understanding and intimacy. Solidarity with the earth calls for a 'synergistic interaction.' This is when two or more characters (in this case, humans and earth) interact so that 'the net effect is greater than the sum of their separate effects' (Miller 1992:147). It is evident that humans cannot exist without the earth. The two are intertwined, they are in synchronous motion, in solidarity towards the positive mutual benefit. Solidarity with the earth calls for interdependence or interrelatedness whereby both humans and the earth are connected to, and intermingled with, each other. Humans are, therefore, called upon not to abuse any of the earth's natural resources, which in this case, is water.

\section{Alternative approach}

Complementarity: The theological interpretation of Genesis 1:26-31 should take the hermeneutical vantage of interdependence as opposed to that of 'grand master over creation'. There must be reciprocity, whereby humans and the earth complement each other. Ted Peters (2000:141) captures it well: 'theologically speaking, we participate with God in the ongoing creative advance.' This is a relation of mutual dependence or influence - a mutual exchange of privileges. Possessing the imago Dei does not provide humans with the right to exploit the earth. Berkhof (1941) admitted:

There is considerable difference of opinion as to whether man's dominion over lower creation also formed a part of the image of God. This is not surprising in view of the fact that Scripture does not express itself explicitly on this point. Some regard dominion in question simply as an office conferred on man, and not as a part of the image. But notice that God mentions man's creation in the divine image and his dominion over the lower creation in a single breath, Gen. 1:26. It is indicative of the glory and honour with which man is crowned, Ps. 8:5, 6 .

(Berkhof 1941:205)

This God-image gives humans the wisdom to interpret nature and sustain and maintain it in a responsible manner. It is this ideal that, if properly understood, restores human dignity. Dignity is not an aberration of the Enlightenment. It has biblical foundation based on the fact that, although God created the cosmos, he finds special delight in humanity (Pr 8:27-31) that is enhanced by the imago Dei. The Dutch theologian, R.C. Sproul (1983) emphasises that:

Man's dignity rests in God who assigns an inestimable worth to every person. Man's origin is not an accident, but a profoundly intelligent act by One who has eternal value; by One who stamps His own image on each person. God creates men and moves heaven and earth to redeem them when they fall. Our origin is in creation and our destiny is for redemption. Between these points every human heartbeat has value.

(Sproul 1983:94)

\section{Alternative approach}

Stewardship: The theological stewardship of the natural resources, such as water, begins with Genesis 1. This is the foundation of the Christian dogma relating to the responsibility of preserving of what God had created. Stewardship is an acknowledgement that everything comes from God as a gift and 
is to be administered faithfully on his behalf. Wealth is derived from the finite resources of the planet, so stewardship must also be concerned with issues of ecological and political exploitation. Theology must seek a just, participatory and sustainable society that respects the integrity of creation. Saving the planet, which includes the proper management of water, calls for faithful and accountable stewardship.

Humans are the stewards, not the owners. They manage the earth on behalf of God, the officers in responsible position of taking charge. They are directly responsible to God for the use of the earth and its resources. They know that the earth does not belong to them but to God and, therefore, are obligated to manage it in the most God-honouring manner possible. In Genesis 1:2, the Creator shapes more complex emergent forms out of the primordial energy, the 'great deep' of potentiality. The creative Spirit moves over the waters of the great deep, the sea of primal chaos, bringing order out of chaos - an example for the nature of human responsibility. Humanity is expected to be proactive in the preservation and sustenance of water as a resource essential for the earth's survival. They follow a bold but cautious (audax et cautus) approach. Sallie McFague's (2008:89) view is that 'if, for instance, our main ecological problem is the scarcity of nonrenewable resources... then human ingenuity might well fill the gaps when shortages occur'. Humanity is not peripheral to the universe. Human beings are 'part and parcel' of the cosmos and must see themselves as such. They have been created as such and they will end up as such. Keith Ward rightly asserts that

humans are not spiritual substances dropped into the material world as alien intruders. They are parts of a continuum of growing complexity in the material order, realizing possibilities implicit in that order from the beginning.

(Ward 1999:27)

God gave Adam (humans) the liberty of stewardship over His creation. To replenish (kabash) means to fill something that was previously emptied. Humanity was created for God's glory and for fulfilment of God's creation. Instead of humans being the apex of creation, they are the fulfilment of creation. Humans were the late-comers into an already created planet. They complete God's original intention of creation and bring to completion what was earlier incomplete. The earth without humanity is incomplete. The command was that they must rule. This means they had to be in charge - to be managers, the 'good stewards'. Human creation was a unique event, 'for unlike other creatures, humans are the result of a consultation between God and certain beings designated as "us"' (Habel \& Trudinger 2008:6). Their uniqueness is further enhanced by the imago Dei they carry and the commission given to them to fill the earth with their presence. This puts them on par with the whole creation, while setting them apart for one particular reason: to take care of nature and its resources as a whole. The dominion given to humans is a cooperative one, therefore, they are expected to cooperate with nature. It is a delegated dominion and, as such, carries enormous responsibility. This fact is highlighted by John Stott:

the dominion God has given humankind is a conscientious and caring stewardship which involves the husbanding of the earth's resources. It would be ludicrous to suppose that God first created the earth and then handed it over to us to be destroyed.

(Stott 1990:124)

Water is life. Without it nothing on earth can exist. A substitute for anything else can be created. However, as far as water is concerned, there is no possible substitute. It is not just life but aqua vitae - water of life. Stewardship of water should be a Christian responsibility. There is a need for theological response regarding the usage and management of water. Christian stewardship is for all the natural resources given by the Creator God.

\section{PRACTICAL CONCLUSIONS}

Firstly, there is a need for the acceleration of responsible theological practices for natural resources into the mainstream studies of dogma. This will include and enhance the concept of eco-hermeneutics, where humans and earth are viewed as complementary partners in existence. It is not just zeitgeist - the spirit of the times. It is a reality that needs intentional theological address in the spheres of systematic theology.

Secondly, there must be some ecclesiastical participation in ecological debate, because our theology is emphatic about the fact that God is continuously creating the earth ( $\mathrm{Rm} 8: 19-22)$, and that he has entrusted it to humanity as stewards to tend to it. The doctrine of creation encourages an appropriate respect for the earth, and for the whole material creation, including water.

Thirdly, Christian theologians must think and act ecologically. A Christian theological response to the process of natural recycling and purification of fresh water is to desist from polluting the water and using more than can be replenished. This means refraining from dumping degradable and non-degradable waste into water sources and withdrawing water from slowly renewable underground sources faster than it can be replenished.

Fourthly, theological reflections regarding the ecological crisis should be continuously exercised to guard against human greed, where the focus is economic gain at the expense of environment. The consumer economy is aimed at material affluence, which deliberately sacrifices long-term sustainability for short-term economic gain and is to blame for the depletion of natural resources, including water. Competing commercial interests regarding water have resulted in a bitter socio-political war that needs to be addressed theologically. Theology must opt for responsible ecological stewardship. The ecclesiastical response here is based, not only on solidarity with the underprivileged, but also on respect for the living environment.

Lastly, there must be an embrace of eco-ethics in all spheres of government, institutions, including the church, and the people in general. They are all responsible for the welfare of the world. The human parochial arrogance underlying the depletion of natural resources such as water should be prophetically addressed by the current theological systems. The whole planet shares in the anxiety created by population shifts, inequality in wealth distribution, dwindling natural resources, pollution and the ominous threat of thermonuclear war. There is an urgent need for an ecumenical perspective based on ethical thinking, of a vision of an eschatological kingdom of God. Indeed, as Peters (2000) asserts:

there is a need for middle axioms, principles that mediate between our vision of ultimate harmony and the realistic appraisal of what we can actually do. We need some principles for guidance.

(Peters 2000:378)

The fact remains: water is a scarce commodity, vulnerable to abuse, mismanagement and pollution. All of these elements threaten human survival and the ecosystem at large. There is a need for a theological voice to save the world from the depletion of its natural resources. There are more exploratory researches to be done regarding the protection of water as a resource. This paper is just a brief expression of a concern that permeates all human societies in the world.

\section{REFERENCES}

Berkhof, L., 1941, Systematic theology, The Banner of Truth Trust, London

Boff, L., 1997, Cry of the earth, cry of the poor, Orbis Books, Maryknoll.

Finch, V.C., 1957, Elements of geography: Physical and cultural, 4th edn., McGraw-Hill Book Company, Inc., New York.

Habel, N.C., 2000, Readings from the perspective of Earth, Sheffield Academic Press, Sheffield

Habel, N.C. \& Trudinger, P., 2008, Exploring ecological hermeneutics, Society of Biblical Literature, Atlanta.

Human Development Reports, 2006, Beyond scarcity: Power, poverty and the global water crisis, viewed 3 April 2009, from 
http://hdr.undp.org/en/reports/global/20hdr2006/

Lvovitch, M.I. \& Solokov, A.A., 1976, 'Anthropogenic changes in the hydrosphere', Geoforum 7, 89-98.

Matthews, V.H., 1990, Manners and customs in the Bible, Henrickson Publishers, Peabody.

McFague, S., 1993, The body of God: An ecological theology, Fortress Press, Minneapolis.

McFague, S., 2008, A new climate for theology: God, the world, and global warming, Fortress Press, Minneapolis.

Merrill, E.H., 1994, An historical survey of the Old Testament, 2nd edn., Baker Book House, Grand Rapids.

Miller, G.T., 1992, Living in the environment: An introduction to environmental science, 7th edn., Wadsworth Publishing Company, Belmont.

Moltmann, J., 1985, God in creation: An ecological doctrine of creation, SCM Press, London.

Peters, T., 2000, God - the world's future: Systematic theology for a new era, 2nd edn., Fortress Press, Minneapolis.

Ray, D.K., 2006, Theology that matters: Ecology, economy, and God, Fortress Press, Minneapolis.

Sproul, R.C., 1983, In search of dignity, Regal Books, Ventura.
Stackhouse, M.L., 2000, The local church in a global era: Reflections for a new century, W.B. Eerdmans Publishing Company, Grand Rapids.

Stott, J., 1990, Issues facing christians today: New perspectives on social and moral dilemmas, Marshall Pickering, London.

United Nations, 2006, 2nd World Water Development Report (WWDR2) - Water: A shared responsibility: 4th World Water Forum proceedings, Mexico City, Mexico, March 92006 viewed 19 March 2009, from http://www.unwater.org/ wwdr2-news.html

United Nations, 2009, 3rd World Water Development Report (WWDR3) - Water in a changing world: 5th World Water Forum proceedings, Istanbul, Turkey, March 16 2009, viewed n.d., from http://www.unesco.org/water/wwap/wwdr/

United Nations Environment Programme (UNEP), 2008, Vital water graphics: An overview of the state of the world's fresh and marine water, 2nd edn., viewed 19 March 2009, from http:// www.grida.no/publications/vg/water2

Ward, K., 1999, God, faith $\mathcal{E}$ the new millennium: Christian belief in an age of science, One World Publications, Oxford.

WHO/Unicef Joint Monitoring Programme for Water Supply and Sanitization, n.d., The drinking water and sanitation ladders, viewed 20 March 2009, from http://www.wssinfo.org/ en/welcome.html 